Article 8 - The announcement of distribution shall take place each year on 11 April, the anniversary of the death of H.M. The Empress Shôken.

Article 9 - A sum which shall not exceed twelve per cent of the annual interest on the capital shall be set aside to cover the cost of administering the Fund and of assisting the National Societies concerned in the realization of their projects.

Article 10 - The Joint Commission shall present to each International Conference of the Red Cross and Red Crescent a report on the current financial situation of the Fund, the allocations which have been made since the preceding Conference and the use made of those allocations by National Societies. The International Conference shall transmit this report to the Japanese Imperial Family through the intermediary of the Japanese Red Cross Society.

\title{
Recognition of the Saint Kitts and Nevis Red Cross Society
}

At its meeting on 27 August 1992, the International Committee of the Red Cross announced the recognition of the Saint Kitts and Nevis Red Cross Society (West Indies).

This recognition, which took effect the same day, brings to 152 the number of National Societies which are members of the International Red Cross and Red Crescent Movement. 